\title{
Otel Müşterilerine Yönelik Deneyimsel Pazarlamanın Memnuniyete Etkisi: Kapadokya Örneği*
}

\section{Impact of Experiential Marketing on Hotels' Customers' Satisfaction: The Case of Cappadocia}

Prof. Dr. Kamil UNUR

Mersin Üniversitesi

Turizm Fakültesi, Mersin, Türkiye

E-posta: kunur@yahoo.com.tr
Arş. Gör. Muhammet A. KINIKLI

Mersin Üniversitesi

Turizm Fakültesi, Mersin, Türkiye

E-posta: Muhammet.a.kinikli@gmail.com

\section{Öz}

Çalışmanın amacı, turizm endüstrisi, deneyimsel pazarlama, deneyimsel değer ve müşteri memnuniyeti bağlamında Kapadokya bölgesinde temalı ve temasız otellerde konaklayan turistlerin yaşadıkları deneyimleri ve bu deneyimlere göre memnuniyet düzeylerinin farklılaşıp farkılıaşmadığını ortaya koymaktır. Kolayda örneklem yöntemi kullanılarak, araştırma yapılmasına izin veren 16 temalı otel misafirlerinden 203 ve 23 temasız otel ziyaretçisinden 202 olmak üzere toplamda 405 kullanılabilir anket toplanmıştır. Analizlerde betimleyici istatistiklerin yanı sıra açıklayıcı faktör analizinden yararlanıımışır. Çalışmanın temel bulgusu, deneyimsel pazarlama algısının tüm alt boyutlarında ve memnuniyet düzeylerinde temalı veya temasız otelde konaklama durumuna göre anlamlı bir farkın bulunmuş olmasıdır. Ayrıca algılanan deneyimsel pazarlama ile müşteri memnuniyeti arasında yüksek bir ilişki tespit edilmiştir. Bu yüksek ilişki, deneyimsel pazarlama algısının müşteri memnuniyetinin neredeyse tek başına yarısını (,501) açıklıyor olmasından kaynaklanmaktadır.

Anahtar Kelimeler: Deneyimsel pazarlama, Müşteri memnuniyeti, Temalı oteller ve Kapadokya bölgesi

\section{Abstract}

The aim of this study is to reveal the experiences of tourists staying in themed and other hotels without theme in Cappadocia region in the context of tourism industry, experiential marketing, experiential value and customer satisfaction and whether their satisfaction varies according to these experiences. Using the convenience sampling method, a total of 405 usable questionnaires were collected, 203 of which were from the 16 themed hotel guests and 202 of which were from 23 other hotel visitors. Descriptive statistics and explanatory factor analysis were used. The main finding of the study is that there is a significant difference in all subdimensions of experiential marketing perception and satisfaction levels according to themed hotel or other hotel without theme accommodation. In addition, a high relationship was detected between perceived experiential marketing and customer satisfaction. This high relationship is due to the fact that experiential marketing perception accounts for almost half of customer satisfaction $(, 501)$.

Key Words: Experiential marketing, Customer satisfaction, Themed hotels and Cappadocia region

*Bu çalışma, "Deneyimsel pazarlamanın müşteri memnuniyeti üzerine etkisi: Kapadokya örneği” başlıklı yüksek lisans tezinden üretilmiştir 


\section{Giriş}

Tüketiciler satın alma kararı verirken yalnızca aklını değil duygularını da göz önünde bulundurmaktadır. Çünkü tüketici yalnızca bir ürün almamakta, aynı zamanda ürünle beraber deneyim de satın almaktadır. Bu durum da yaşanan ya da yaşanacak olan deneyimin bireyi duygusal olarak da tatmin etmesi için firmalar tarafından sunulan ürünün sadece fonksiyonel özelliklerine değil, duygusal ve sembolik özelliklerine de odaklanmasını gerektirmektedir (Walls ve Diğ., 2011: 10). Deneyimin bu denli ön plana çıkması, firmaların hem tüketicileri daha yakından ve dikkatli izlemelerini zorunlu kılmakta hem de karar verme süreçlerini ve bu süreçleri etkileyen faktörleri belirlemelerini ve incelemelerini gerekli kılmaktadır (Çiçek ve Kara, 2015: 178). Bu açıdan bakıldığında tüketicilerin incelenmesinin zorunlu olduğu sektörlerden birisi de turizm sektörü olduğu söylenebilir. Çünkü turizm sektörü, müşterilerine turistik ürünü deneyimsel boyut ile harmanlayarak sunmaktadır. Nitekim turistler de bir tatil deneyimi yaşamak istemektedir (Köse, 2015: 2; Güney 2015: 2).

Müşteri deneyimlerinden yararlanan deneyimsel pazarlama, tüketici ile işletme arasında duygusal bağ kuran bir köprü olarak düşünülmektedir (Yuan ve Wu 2008: 5). Deneyimsel pazarlama ile otel işletmeleri sattıkları ürünlerin tüketicilerin ihtiyaçlarını karşılamalarının yanı sıra onlara deneyim yaşatarak onları mutlu ya da memnun etmek istemektedirler. Çünkü memnun müşteriler, bir sonraki satın alma eylemlerinde de aynı işletmeyi tercih etme eğiliminde olacaklardır (Özbay, 2011: 17).

Temalı oteller açısından bakıldığında, mimari tarzlarıyla değişiklik gösteren, gerek var olan yapıya işlev kazandırmak amacıyla gerekse özgün temalar üreterek inşa edilen bu oteller, müşterilerine unutulmaz bir deneyim yaşatabilmeyi amaçlamaktadır. Bu deneyimler sonucunda oluşan memnuniyet, turistlerin gelecek tatil davranışına yön verebilmekte ve destinasyonu yeniden ziyaret etme eğilimine yol açabilmektedir (Atay ve Çeti, 2018: 556). Çünkü temalı oteller konaklama, yeme-içme ve dinlenme amacına göre birçok hizmet sunmanın yanında eğlence, rahatlama, sağlık gibi bütünleyici aktiviteleriyle de müşterilerin ihtiyaçlarına cevap verebilmektedir (Özen, 2009: 56). Bu bağlamda araştırmanın amacı, otellerin temalı/temasız olmasının müşterilerin deneyimleri ve memnuniyetleri üzerine etkisini ortaya koymaktır.

\subsection{Deneyim ve Deneyimsel Pazarlama}

Türk Dil Kurumu (2018) "deneyim" sözcüğünü; "Bir kimsenin belli bir sürede veya hayat boyu edindiği bilgilerin tamamı, tecrübe, eksperyans" ve "bilgi ve beceri kazandırıcı bilinçli ya da bilinçsiz kişisel edinim ve yaşantı" olarak tanımlamaktadır. Deneyim konusunda yapılan pek çok tanım var ise de tüm araştırmacılar tarafından kabul edilen bir tanım henüz mevcut değildir (Jurowski, 2009:1). Schmitt'e (1999) göre deneyimler, kendiliğinden oluşmayan, hazırlanmış bir durumun sonucunda meydana gelen ve genel durumu etkisine alan yaşantılardan oluşmaktadır. Tüketim olgusunda deneyim, bireysel katılımın sağlanması ile birlikte bireyin duruma fiziksel, mantıksal, duygusal, sosyal ve ruhsal olarak dahil olması ile oluşmaktadır (O'Sullivan ve Spangler, 1998). Pazarlama ve tüketici davranışları açısından deneyim ise tüketiciler tarafından eşsiz, unutulmaz, sürdürülebilir, anlatılarak tekrarlanan ve şevkle kulaktan kulağa tanıtımın yapılabileceği yaşantılardır (Pine ve Gilmore, 1998: 97).

Turizm alanında deneyim kavramını ilk ortaya çıkaran çalışma Csikszentmihalyi tarafından 1975 yılında gerçekleşmiştir (Harman ve Akgündüz, 2014: 116-117). Turizm ürünü açısından deneyim, üretim ve tüketimin meydana gelmesiyle oluşmaktadır. Deneyimler, önceden yapılandırılmış bir durumun akabinde oluşan ve genel atmosferi 
etkisi altına alan durumlardan biridir. Bu bağlamda müşteriye bilginin, duyusal ve duygusal etmenlerin sunulması deneyimin oluşmasına olanak tanımaktadır (Yuan ve Wu, 2008:388). Oluşan bu turizm deneyimi karmaşık bir yapı teşkil etmektedir.

Turizm sektöründe işletmeler müşterilerin hatırlayabileceği eşsiz deneyimleri sunmak için mal ve hizmet, fiyat, dağıtım, tutundurma, insan, fiziksel olanaklar ve işlem yönetimi gibi hizmet pazarlama karması elemanlarını deneyim ile zenginleştirmektedir. Hizmet yoğun özelliği ve ürünün üretildiği anda tüketilmesinden dolayı turizm işletmelerinde çalışanlar bir tiyatro oyuncusu, otel, restoran, müze, eğlence işletmeleri, temalı parklar ve destinasyonlar ise birer tiyatro sahnesi olarak nitelendirilebilir (Pine ve Gilmore, 1999).

Deneyimsel pazarlamayı ilk olarak ortaya atan ve kavramsallaştıran Schmitt (1999: 53-54), deneyimsel pazarlamanın bilgi teknolojilerinin gelişmesi, markaların genişlemesi ile farklı alanlara kayan markaların üstünlüğü, iletişim ve eğlencenin her yerde bulunması şeklinde üç başlıkta ortaya çıktığını söylemektedir. Deneyimsel pazarlama, hedef kitlenin yarar sağlayacağı iki yönlü iletişim içerisinde, marka kişiliği ve ilave değerler sunarak hedef kitlenin isteklerinin ve intiyaçlarının tatmin edildiği pazarlama türünü oluşturmaktadır. Yuan ve Wu (2008) deneyimsel pazarlamanın tüm fiziksel çevre unsurlarını sahnelemek için işletme tarafından tasarlanmış bir strateji olduğunu vurgulayarak, deneyimsel pazarlamayı tüketicilerin bu deneyimi kazanmak için katıldıkları işlevsel bir süreç olarak tanımlamaktadır.

Deneyimsel pazarlamada amaç turistlerin tüketim olayına tam olarak dâhil edilmesini sağlamaktır. Turizm olayına tam olarak dahil olunmasından kasıt turistlerin duyularına ve duygularına hitap edebilmektir (Holbrook ve Hirshman, 1982). Turizm sektöründe deneyimsel pazarlamayı uygulamak bir tüketici olarak turistleri tanımak, anlamak ve ortamı turist odaklı dizayn etmekle mümkün olabilmektedir. Örneğin, Roma uygarlığı sembolleri ile bezenmiş villalarda, saman çatılı malikânelerde, otantik şeyh çadırlarında ve uzay kapsüllerinde konaklayarak eşsiz konaklama deneyimi elde eden turistler, söz konusu turistik ürünü unutamayacaklardır (O'sullivan ve Spangler, 1998: 3).

\subsection{Deneyimsel Pazarlama ve Temalı Oteller}

Günümüz tüketicisi hizmet sağlayıcıların verdiği hizmetlerin sıradanlaşmasından dolayı farklııı aramaya başlamıştır. Tüketicilerin bu isteğini anlayıp farklı ürünler sunan işletmeler rekabet üstünlüğü elde etmektedir. Rekabet açısından turizm sektöründe de aynı durum geçerlidir (Milman, 2001: 1). Bu anlamda, daha fazla deneyim elde edebileceği destinasyonlara ve faaliyetlere yönelen turistlere farklı deneyimler sunmak için temalı oteller ortaya çıkmıştır (Dilsiz, 2010).

Temalı otellerin ilki 1950'li yıllarda ABD'nin Nevada eyaletinin Las Vegas kentinde Walt Disney tarafından inşa edilmiştir. Bölgenin çöl olması nedeniyle otel, mimarlar tarafından hem iç hem de dış tasarımıyla çekici hale getirilmeye çalışılmıştır (Akkaya ve Usman, 2011: 71; Özen, 2009: 62). Türkiye'deki temalı otellerin başında Topkapı Palace Oteli gelmektedir. Topkapı Palace Oteli'ni Kremlin Palace, Venezia Palace, Titanik, Concorde Resort-Spa Oteli, Miracle Resort Oteli ve Mardan Palace Oteli izlemektedir (Atay ve Çeti, 2018:5).

Gilmore ve Pine'a göre (2002) tema, bir hizmeti deneyime dönüştüren temel bir kavramdır. Bu düşünceden hareketle temalı otellerde, turistin farklı olanı deneyimleme isteğine cevap bulabilmesi gerekmektedir. Böylelikle yeni deneyimler edinme arayışı 
içerisinde olan müşterilerin tercihlerinde temalı oteller bir seçenek olabilir. İşletmeler açısından değerlendirildiğinde ise deneyimsel pazarlama faaliyetleri temalarını sahnelemek için bir yol ya da bir fırsat olabilir (Pine ve Gilmore, 1999: 47).

\subsection{Müşteri Memnuniyeti}

Rekabetin yoğunlaşması ve bilgi teknolojilerinin gündelik hayata daha çok girmeye başlaması ile müşterilerin beklentileri artmaktadır. Bu durum da müşteri memnuniyetini zorlaştırmaktadır. Günümüzde daha bilgili ve bilinçli olan müşteriler tam olarak ne istediklerini bilerek seçim yapmaktadır (Genç, 2009: 83). Genel olarak memnuniyet, müşterinin yerine getirilmesini istediği veya beklediği karşılık olarak ifade edilmektedir (Oliver, 2015: 8). Müşteri memnuniyeti, satın alınan üründen beklenen faydanın ürün tarafından karşılanması durumunda ortaya çıkmaktadır (Kılıç ve Pelit, 2004). Bu bağlamda işletmeler için en önemli stratejilerden biri müşteri memnuniyetini ve tatminini sağlamaktır. Memnuniyet ve tatmin kavramları alan yazında eş anlamlı olarak kullanılmasına karşın birbirinden farklı kavramlardır. Memnuniyetten ayrı olarak düşünülen tatmin kavramı Oliver'a göre, (1997) "memnuniyet doygunluğu" olarak ifade edilmektedir. Tatmin kavramı ayrıca, tüketicinin bazı istek ve beklentilerinin memnuniyet verici düzeyde karşılanmış olması olarak da açıklanabilmektedir (Altıntaş, 2000: 29).

Turizm açısından bakıldığında turist, tüketici veya müşteri olarak değerlendirilmektedir. Turistin memnun olması, sunulan turistik mal veya hizmet performansını, beklenti ve tercihlerle karşılaştırması neticesinde ortaya çıkmaktadır (Değirmencioğlu, 2001: 51). Bu bağlamda turizmde müşteri memnuniyeti, turistik ürün tüketicisinin beklentileriyle paralel ilerleyen bir süreç olup (Bulgan ve Soybalı, 2011: 3574), müşterilerin toplam turistik deneyimlerini içermektedir (Bassi ve Guido, 2006: 83).

\subsection{Literatür Taraması}

Konuyla ilgili Türkçe ve İngilizce literatür incelendiğinde çalışmaların daha çok deneyimsel tüketimi kapsadığı (Holbrook ve Hirschman1982; Kara ve Çiçek, 2015; Harman ve Akgündüz, 2014; Güney,2015; Gentile, Spiller ve Noci, 2007; Çeltek, 2010; Bassi ve Guido, 2006; Ardıç, 2015) ve az sayıda da deneyim ve temalı otellerin içinde bulunduğu çalışmaya rastlanmış olduğu görülmektedir (Atay ve Çeti 2018; Hung 2015; Milman, 2008).

Örneğin, Atay ve Çeti (2018), çalışmasında temalı turizm işletmesi olan botellerde (gemi ve tekne temalı otel) konaklayan turistlerin yaşadıkları deneyimlerin belirlenmesini amaçlamıştır. Çalışmada Prag'da booking.com üzerinde en yüksek ve en düşük puanı almış iki botel seçilmiş ve bu botellerin aldıkları yorumlar incelenmiştir. Sonuç olarak; turistlerin botel temasından yola çıkarak botellerin tasarımsal özelliklerinden oldukça etkilendikleri ve bu doğrultuda da temaya bağlı olarak elde ettikleri deneyimlerini olumlu bir şekilde değerlendirdikleri saptanmıştır.

Deneyimsel pazarlamanın memnuniyet üzerinde etkili olduğunu gösteren çalışmalara bakıldığında, Köse (2015) deneyimsel pazarlama unsurlarını İstanbul destinasyonuna uyarlamış ve bu unsurların İstanbul'u ziyaret eden üçüncü yaş turistlerinin tatmin düzeylerine ve davranışsal niyetlerine olan etkisini incelemeyi amaçlamıştır. Sonuç olarak duygusal deneyim boyutunun memnuniyeti doğrudan etkilediğini bulgulamıştır. Ali, Ryu ve Hussain (2016) yapmış oldukları çalışmada yaratıcı turizm deneyiminin anılar, memnuniyet ve davranışsal niyet üzerindeki 
etkilerini araştırmışlardır. Çalışmada oluşturulmaya çalışılan ölçekten elde edilen sonuçlar doğrultusunda deneyimin memnuniyetin iyi bir tahmin edicisi olduğu belirtilmektedir. Hung (2015) çalışmasında Çin'deki otellerdeki Budizm deneyimini ele almıştır. Dini amaçla hareket eden turistlerin konakladıkları otellerin dini temalı oteller olması halinde Budizm'le iç içe olunacağından hem yaşadıkları deneyimin hem de memnuniyet düzeylerinin artacağı sonucuna ulaşılmıştır. Rather (2020) yapmış olduğu çalışmada deneyimsel pazarlama perspektifinden müşteri deneyimini ve müşterilerin turizm destinasyonlarına katılımlarını incelemiştir. Deneyimsel pazarlama konusunda, destinasyonu tekrar ziyaret eden müşterilerin ilk kez destinasyonu ziyaret edenlere kıyasla daha fazla deneyim edindiği sonucuna ulaşılmıştır. Chen, Wong, Bilgihan ve Okumuş (2020) yapmış oldukları çalışmada Japonya'da bulunan kapsül temalı otelleri en iyi uyarılmışlık seviyesi modeli ile incelemişlerdir. Bulgu olarak, en iyi uyarılmışlık seviyesinin deneyimsel değer ve algılanan risk üzerinde olumlu bir etkiye sahip olduğu gözlenmiştir. Çalışmada deneyimsel değerin de algılanan riski olumsuz etkilediği tespit edilmiştir. Deneyimsel değerin ayrıca algılanan risk ile en iyi uyarılmışlık seviyesi arasında aracılık rolü oynadığı yorumu da yapılmıştır.

\subsection{Araştırmanın Amacı}

Turizm insanların yeni deneyimler edinme anlayışından yola çıkarak gerçekleştirdikleri yer değiştirme eyleminden doğan bir kavramdır. Kavramın odağını insan oluşturduğu için diğer hizmet sektörlerine göre turizm sektöründe ilişkilerin yoğun olması beklenen bir durumdur. Bu ilişkiler çerçevesinde işletmeler müşterilerini memnun etmek adına deneyimsel pazarlama faaliyetlerinde bulunmaya, müşteriler ise sunulan bu hizmetlerden maksimum deneyim elde etmeye çalışmaktadır.

Turizm sektörü, deneyimsel pazarlama, deneyimsel değer ve müşteri memnuniyeti bağlamında araştırmanın amacı; Kapadokya bölgesinde temalı ve temasız otellerde konaklayan turistlerin yaşadıkları deneyimleri ve bu deneyimlere göre memnuniyetlerinin farklılaşıp farklılaşmadığını belirlemektir. Bir başka ifadeyle; turistlerin memnuniyetinin ve deneyimlerinin temalı ve temasız otelde konaklayıp konaklamadıklarına, otel dışında balon deneyimi yaşayıp yaşamadıklarına ve çeşitli değişkenlere göre farklılaşma durumlarını tespit etmek araştırmanın temelini oluşturmaktadır. Turistlerin Kapadokya ya özel balon deneyimi yaşayıp yaşamadıklarının merak edilmesindeki amaç, turistlerin bölgede otel dışında yaşamış oldukları fazladan deneyimin, genel otel deneyimini ve memnuniyetini ne düzeyde etkileyebileceğinin ortaya çıkarılmasıdır.

Araştırmanın kapsamını, teorik bağlamda deneyimsel pazarlama, deneyimsel değer ve müşteri memnuniyeti oluşturmaktadır. Uygulama alanını ise; Kapadokya bölgesindeki temalı ve temasız otelleri ziyaret eden turistler meydana getirmektedir. Bunlara ek olarak; araştırma kapsamında deneyimsel pazarlama faaliyetlerinin müşteri memnuniyeti sağlamada nasıl yönetilebileceği de irdelenmeye çalışılmıştır.

Çalışmada yukarıda belirtilen amaçlar doğrultusunda, aşağıdaki araştırma sorularına cevap aranmaktadır:

1- Temalı ve temasız otelde konaklayan ziyaretçilerinin deneyimsel pazarlama algıları ne düzeydedir?

2- Ziyaretçilerin kaldıkları otel çeşidine göre deneyimsel pazarlama algılamalarında ve memnuniyet düzeylerinde anlamlı bir farklılık var mıdır?

3- Kapadokya bölgesindeki bir otelde konaklayan turistlerin deneyimsel pazarlama algıları ve memnuniyetleri demografik özelliklere, beraber 
konakladıkları kişilere ve tatillerini planlama şekillerine göre farklılaşmakta midır?

4- Kapadokya bölgesindeki bir otelde konaklayan turistlerin deneyimsel pazarlama algıları ve memnuniyetleri otel dışında yaşadıkları balon deneyimine göre farklılaşmakta mıdır?

5- Kapadokya bölgesindeki bir otelde konaklayan turistlerin deneyimsel pazarlama algıları ile genel memnuniyet düzeyleri arasında anlamlı bir ilişki var mıdır?

6- Kapadokya bölgesindeki bir otelde konaklayan turistlerin deneyimsel pazarlama algılarının genel memnuniyet düzeyleri üzerinde anlamlı bir etkisi var mıdır?

\section{Araştırmanın Yöntemi}

Bu araştırma, temel olarak Kapadokya Bölgesine gelen ve temalı ile temasız otellerde konaklayan yabancı turistler özelinde otel temasının müşteri memnuniyetine etkisini belirlemek amacıyla tasarlanmıştır. Araştırma, değişkenler arasındaki ilişkiyi ve ilişkinin derecesini ortaya çıkarmayı amaçladığından, genel tarama modellerinden ilişkisel tarama modeli kapsamında oluşturulmuştur. İlişkisel tarama modeli, iki ve daha çok sayıdaki değişken arasında birlikte değişimin varlığını ve/veya derecesini belirlemeyi amaçlayan araştırma modellerinden oluşmaktadır (Karasar, 2018: 114).

Araştırmanın evrenini Kapadokya'ya gelen yabancı turistler oluşturmaktadır. Araştırmanın evreni olarak Kapadokya'nın seçilmesinin nedeni bölgenin kendine özgü eşsiz coğrafi yapısı ve bu yapı nedeniyle mağara ve benzeri şekillerde temalı otel sayısının diğer bölgelere göre çok olması ve araştırmanın yapıldığı tarih diliminde bölgeyi ziyaret eden yabancı turist sayısının fazla olmasıdır. Kapadokya'ya gelen turist sayıları Kültür ve Turizm Bakanlığı verilerinden elde edilmiş ve araştırmanın evreninin 422.847 kişi olduğu tespit edilmiştir (Kültür ve Turizm Bakanlığı, 2018).

Araştırmacılar tarafından araştırmanın amacına uygun olacak şekilde birincil verilere ulaşmak üzere öncelikle bölgedeki oteller temalı ve temasız olmak üzere ikiye ayrılmıştır. Temalı otellere Nevşehir Kültür ve Turizm Müdürlüğü'nün yayınladığı konaklama tesisleri listesinin "Özel Konaklama Tesisleri" kısmından erişilmiş ayrıca web siteleri ziyaret edilerek teyit edilmiştir. Kapadokya Bölgesi'nde toplamda 98 otel olduğu, bu otellerinde 36 tanesinin temalı ve 62 tanesinin de temasız otel olduğu tespit edilmiştir. Daha sonra kolayda örneklem yöntemi kullanılarak, yani araştırma yapılmasına izin veren 16 temalı otelden 203 anket ve 23 temasız otelden 202 anket olmak üzere toplamda 405 kullanılabilir anket toplanmıştır. Veriler 30 Ekim -26 Kasım 2018 tarihleri arasında araştırmacı tarafından bırak topla ve yüz yüze görüşme yöntemiyle İngilizce bilen yabancı turistlerden toplanmıştır.

Araştırmanın verilerini toplamak için, veri toplama yöntemlerinden anket tekniği kullanılmıştır. İngilizce olarak hazırlanan anket formunun birinci bölümünde ankete katılan yabancı turistlerin sosyo-demografik özelliklerine ilişkin 8 soru sorulmuştur. Anket formunun ikinci bölümü katılımcıların seyahatlerine ilişkin 3 adet çoktan seçmeli sorudan oluşmaktadır. Anket formunun üçüncü bölümünde Lin (2006) tarafından geliştirilen ve Güney (2015) tarafından Türkçeye uyarlanan 19 maddelik "Deneyimsel Pazarlama Algısı" ölçeğine yer verilmiştir. Dördüncü bölüm ise Lin (2005) tarafından geliştirilen 5 maddelik "Müşteri Memnuniyeti" ölçeğine Bak (2015) tarafından geliştirilen turist memnuniyeti ölçeğinden 2 madde eklenerek oluşturulmuştur. Güney tarafından Türkçeye uyarlanan "Deneyimsel Pazarlama Algısı" ölçeği, memnuniyet ölçeğine eklenen 2 madde ve ankette yer alan diğer Türkçe sorular önce konusunda uzman 
olan 3 öğretim üyesi tarafından incelenmiştir. Ardından sorular İngilizceye çevrilmiştir. İngilizceye çevrilen maddeler tekrar Türkçeye çevrilmiş ve böylelikle çeviride sorun olmadığı görülmüştür. Son olarak tüm anket için 22-30 Ekim 2018 yılında Kapadokya bölgesinde 90 turist üzerinde pilot çalışma yapılarak ankete son şekli verilmiştir. Ölçeklerde 5'li likert tipi dereceleme kullanılmış ve katılımcılardan ölçekte yer alan ifadelere, "(1) Kesinlikle Katılmıyorum, (2) Katılmıyorum, (3) Kararsızım, (4) Katılıyorum ve (5) Kesinlikle Katılıyorum" derecelendirmelerinden birini kullanarak yanıt vermeleri istenmiştir. Bu çalışmaya 2017 yılından önce başlandığı için etik kurul raporu alınmamıştır, ancak akademik etik kurallara hassasiyetle uyulmuştur.

\section{Bulgular}

Anket formuna yanıt veren katılımcıların demografik özelliklerine ilişkin bilgiler Tablo 1 'de verilmiştir. Tablo incelendiğinde; katılımcıların \%51'inin erkek olduğu ve \%71'inin 22- 36 yaş grubunda olduğu görülmektedir. Katılımcıların medeni durumları incelendiğinde; \%70,6'sının bekâr olduğu, eğitim durumlarına bakıldığında ise; \%36'sının ön lisans mezunu olduğu anlaşılmaktadır. Anket formuna cevap verenlerin meslekleri incelendiğinde; \%56'sının öğrenci olduğu görülmektedir. Katılımcıların milliyetlerine bakıldığında; \%13'ünün İspanyol olduğu anlaşılmaktadır. Katılımcıların aylık hane halkı gelir düzeyleri Euro ve Dolar kuru üzerinden iki farklı döviz türüne göre incelenmiştir. Katılımcıların \%73,3'ü maaş ile ilgili soruyu Euro olarak cevaplarken, \%26,7'si Dolar olarak cevaplamıştır. Maaşlarını Dolar kuru üzerinden aldıklarını ifade eden katıımcıların \%27'si, 1001-1500 Dolar arası maaş alırken, maaşlarını Euro kuru üzerinden aldıklarını ifade eden katılımcıların \%62'si, 1000 Euro ve daha az maaş almaktadır. Turistler tarafından beyan edilen gelirler analizlerin yapıldığı tarihteki (2112-2018) geçerli kurlar (Avro/Dolar paritesi 1,14) üzerinden Amerika Birleşik Devletleri (ABD) Dolarına çevrilmiş ve Tablo 1'e Dolar olarak yazılmıştır.

Tablo 1: Katılımcıların Demografik Özellikleri

\begin{tabular}{|l|c|c|c|c|c|c|c|}
\hline Değişken & $\mathbf{N}$ & Frekans & Yüzde(\%) & Değişken & $\mathbf{N}$ & Frekans & Yüzde (\%) \\
\hline Cinsiyet & 405 & & & Milliyet & 405 & & \\
\hline Kadın & & 198 & 48,9 & İspanyol & & 54 & 13,3 \\
\hline Erkek & & 207 & 51,1 & Leh (Polonyalı) & & 49 & 12,1 \\
\hline Yaş & 405 & & & Hintli & & 35 & 8,6 \\
\hline $18-21$ & & 30 & 7,4 & Alman & & 33 & 8,1 \\
\hline $22-36$ & & 286 & 70,6 & İtalyan & & 33 & 8,2 \\
\hline $37-52$ & & 53 & 13,1 & Çinli & & 26 & 6,4 \\
\hline 53 ve üzeri & & 36 & 8,9 & Japon & & 21 & 5,2 \\
\hline $\begin{array}{l}\text { Medeni } \\
\text { durum }\end{array}$ & 405 & & & Leton & & 19 & 4,7 \\
\hline Evli & & 119 & 29,4 & Malezyalı & & 16 & 4,0 \\
\hline Bekâr & & 286 & 70,6 & Güney Koreli & & 15 & 3,7 \\
\hline Eğitim & 405 & & & Macar & & 14 & 3,5 \\
\hline İlköğretim & & 8 & 2,0 & Rus & & 13 & 3,2 \\
\hline Lise & & 47 & 11,6 & Roman & & 12 & 3,0 \\
\hline Ön lisans & & 147 & 36,3 & Fransı & & 8 & 2,0 \\
\hline Lisans & & 144 & 35,6 & Amerikan & & 8 & 2,0 \\
\hline Yüksek lisans & & 53 & 13,1 & Diğer* & & 49 & 11,6 \\
\hline Doktora & & 6 & 1,5 & n & & & \\
\hline
\end{tabular}


Tablo 1'in devamı

\begin{tabular}{|l|c|c|c|c|c|c|c|}
\hline Meslek & 405 & & & Döviz cinsi & 405 & & \\
\hline Öğrenci & & 228 & 56,3 & Dolar & & 108 & 26,7 \\
\hline İş̧i & & 57 & 14,1 & Euro & & 297 & 73,3 \\
\hline Öğretmen & & 23 & 5,7 & Gelir (Avro) & 405 & & \\
\hline Memur & & 22 & 5,4 & 1000 veya altı & & 202 & 49,9 \\
\hline İş adamı & & 20 & 4,9 & $1001-1500$ & & 72 & 17,8 \\
\hline Emekli & & 19 & 4,7 & $1501-2000$ & & 37 & 9,1 \\
\hline Sağlık çalışanı & & 10 & 2,5 & $2001-2500$ & & 22 & 5,4 \\
\hline Yönetici & & 8 & 2,0 & $2501-3000$ & & 24 & 5,9 \\
\hline İşsiz & & 8 & 2,0 & $3001-4500$ & & 25 & 6,2 \\
\hline Ev hanımı & & 5 & 1,2 & $4501-5000$ & & 1 & 0,2 \\
\hline Avukat & & 4 & 1,0 & $5001-7500$ & & 11 & 2,7 \\
\hline Mühendis & & 1 &, 2 & $7501-10000$ & & 3 & 0,7 \\
\hline & & & & 10001 veya & & 8 & 2,0 \\
\hline
\end{tabular}

*3 veya daha az ziyaretçiye sahip 17 ülkeden katılımcı sayısı

Veri analizinde çok değişkenli parametrik istatistik tekniklerinin kullanılacak olması nedeniyle, iki ölçeğe de çoklu sapan ve çoklu normal dağılım analizleri yapılmıştır. Çoklu sapan analizi, uç değerlerin varlığını test etmek için yapılmaktadır. Uç değerler, bir katılımcının bir değişken ya da değişken kombinasyonu için sahip olduğu aşırı değeri ifade etmektedir. Bu değerlerin çok değişkenli analizlerde problemlere neden olabileceğinden kontrol edilmesi gerekir (Çokluk, Şekercioğlu ve Büyüköztürk, 2012: 10). Sonuç olarak çalışmanın veri seti, her iki ölçek için de çoklu normal dağılım göstermektedir ve her iki ölçekte de çoklu sapan değerine sahip olan herhangi bir maddeye rastlanmamıştır.

Çoklu sapan analizi ve çoklu normal dağılım analizleri gerçekleştirildikten sonra, araştırmanın amacına uygun tanımlayıcı istatistiklerin yanı sıra, güvenirlik analizi, açıklayıcı faktör analizi, t-testi, ANOVA, korelasyon ve regresyon analizleri yapılmıştır.

Araştırmada Deneyimsel Pazarlama Algısı ölçeğinin Alfa Güvenirlik katsayısı .914 olarak bulunmuştur. Aynı katsayı Müşteri Memnuniyeti ölçeği için ,919 olarak hesaplanmıştır. Ölçekler ikiye ve örneklem rastgele ikiye bölünerek ve ayrıca tek ve çift numaralı ölçek maddelerine göre ölçeklerin güvenirlik katsayıları hesaplanmış ve hepsinin 0,800 'ün üstünde olduğu görülmüştür. Böylece ölçeklerin güvenilir olduğu sonucuna ulaşıımıştır (Alpar, 2013: 847). Yapılan güvenirlik analizinin ardından her iki ölçekte açıklayıcı faktör analizine tabi tutulmuştur. Deneyimsel pazarlama algısı ölçeğine uygulanan faktör analizi sonucunda ölçek 3 faktör altında toplanarak toplam varyansın \%58,817'sini açıkladığı tespit edilmiştir. Bu boyutlara "Sosyalleşme ve Merak", "Hizmet Atmosferi" ve "Ambiyans" isimleri verilmiştir. Müşteri memnuniyeti ölçeğine uygulanan açıklayıcı faktör analizi sonrasında tek boyut oluştuğu görülmüş ve oluşan bu boyuta "Müşteri Memnuniyeti" adı verilmiştir. Deneyimsel Pazarlama Algısı ölçeğinin faktör analizi Tablo 2'de yer almaktadır. 
Tablo 2: Deneyimsel Pazarlama Algısı Ölçeği Açıklayıcı Faktör Analizi

\begin{tabular}{|c|c|c|c|c|c|}
\hline & 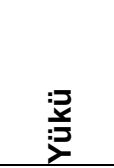 & 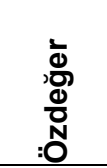 & 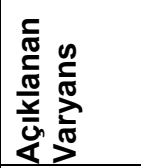 & $\begin{array}{l}\frac{\pi}{5} \\
\frac{\pi}{\pi} \\
\text { ప̃ }\end{array}$ & $\frac{\pi}{4}$ \\
\hline 1. Sosyalleşme & & 4,132 & 24,308 & 3,749 & 0,858 \\
\hline $\begin{array}{l}\text { Buraya gelişim arkadaşlarımla } \\
\text { geliştirecek. }\end{array}$ & 0,763 & & & & \\
\hline $\begin{array}{l}\text { Bu otelde konaklamak, benimle ortak ilgi alanına sahip olanlarla } \\
\text { deneyim alışverişi yapmamı sağladı. }\end{array}$ & 0,748 & & & & \\
\hline $\begin{array}{l}\text { Konakladığım otelde yaşadıklarımı sosyal çevremle (akraba, } \\
\text { arkadaş vb.) paylaşacağım. }\end{array}$ & 0,720 & & & & \\
\hline $\begin{array}{l}\text { Konakladığım otelde yapılan etkinlikler bende katılma isteği } \\
\text { uyandırdı. }\end{array}$ & 0,687 & & & & \\
\hline Otel deneyimi, aile üyelerini ve arkadaşları yakınlaştıır. & 0,642 & & & & \\
\hline Bu otel deneyiminden önemli tecrübeler edindim. & 0,596 & & & & \\
\hline Otelin iç ortamı bende merak uyandırdı. & 0,565 & & & & \\
\hline 2. Hizmet Atmosferi & & 3,752 & 22,071 & 3,8193 & 0,890 \\
\hline $\begin{array}{l}\text { Konakladığım otelin restoranında sunulan yiyecek ve içecekler } \\
\text { lezzetliydi. }\end{array}$ & 0,843 & & & & \\
\hline $\begin{array}{l}\text { Konakladığım otelin restoranında yöresel yiyecek ve içecekler } \\
\text { sunuldu. }\end{array}$ & 0,807 & & & & \\
\hline $\begin{array}{l}\text { Konakladığım otelin restoranında sunulan yiyecek ve içecekler } \\
\text { tazeydi. }\end{array}$ & 0,802 & & & & \\
\hline Konakladığım otel odaları fiziksel olarak konforlu ve rahattı. & 0,669 & & & & \\
\hline $\begin{array}{l}\text { Konakladığım otelin ortamı günlük hayattaki sıkıntılardan } \\
\text { uzaklaşmamı sağladı. }\end{array}$ & 0,627 & & & & \\
\hline Otel içindeki ortam beni neşelendirdi. & 0,532 & & & & \\
\hline 3. Ambiyans & & 2,376 & 13,977 & 3,2537 & 0,753 \\
\hline Konakladığım otelde çalınan müzik dikkatimi çekti. & 0,823 & & & & \\
\hline Konakladığım otelin ışıklandırma sistemi ilgimi çekti. & 0,821 & & & & \\
\hline Konakladığım otelin misafir odalarının dekorasyonu ilgimi çekti. & 0,597 & & & & \\
\hline Misafir odalarının dekorasyonu bende merak uyandırdı. & 0,523 & & & & \\
\hline \multicolumn{6}{|c|}{ 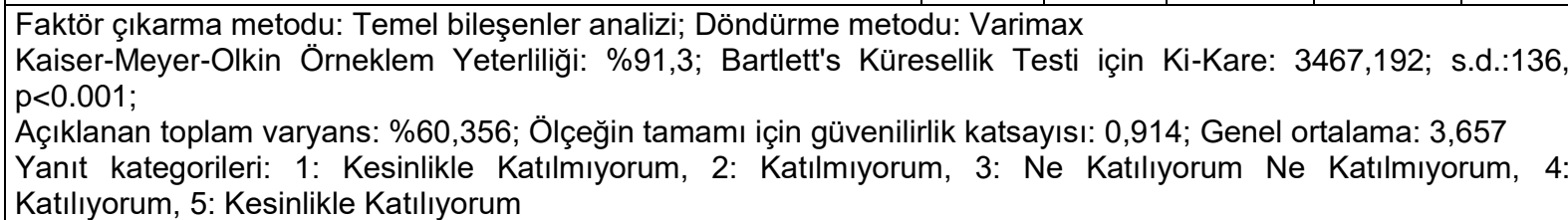 } \\
\hline
\end{tabular}

Araştırmaya dahil olan katılımcıların seyahat deneyimlerine ilişkin bulgular Tablo 3'te sunulmuştur. Tablo incelendiğinde, 215 kişinin $(\% 53,1)$ arkadaşları ile seyahat ettiği ve 326 kişinin $(\% 80,5)$ ise seyahat acentesi kullandığı tespit edilmiştir. Katılımcılardan 344 kişinin $(\% 84,9)$ balon deneyimi yaşadığı ve 203 kişinin $(\% 50,1)$ temalı otelde konakladığı tespit edilmiştir. 
Tablo 3: Katılımcıların Seyahat Deneyimlerine İlişkin Bulgular

\begin{tabular}{|l|l|c|c|c|c|c|c|}
\hline Değişken & $\mathbf{N}$ & Frekans & Yüzde (\%) & Değişken & $\mathbf{N}$ & Frekans & Yüzde (\%) \\
\hline $\begin{array}{l}\text { Tatile kiminle } \\
\text { çıktınız? }\end{array}$ & 405 & & $\begin{array}{l}\text { Tatilinizi nasıl } \\
\text { organize ettiniz? }\end{array}$ & 405 & & \\
\hline Yalnız & & 39 & 9,6 & Bireysel & & 79 & 19,5 \\
\hline Aile & & 122 & 30,1 & Seyahat acentesi & & 326 & 80,5 \\
\hline Arkadaş & 215 & 53,1 & $\begin{array}{l}\text { Balon deneyimi } \\
\text { yaşadınız mı? }\end{array}$ & 405 & & \\
\hline Her ikisi & & 29 & 7,2 & Evet & & 344 & 84,9 \\
\hline $\begin{array}{l}\text { Konaklanan } \\
\text { otel türü }\end{array}$ & 405 & & & Hayır & & 61 & 15,1 \\
\hline Temalı & & 203 & 50,1 & & & & \\
\hline Temasız & & 202 & 49,9 & & & & \\
\hline
\end{tabular}

Tatile kiminle çıkıldığı sorusuna verilen yanıtlar incelendiğinde her ikisi (aile ve arkadaş) ile tatile çıkanların sayısının 29 olduğu gözlemlenmiştir. Merkezi limit teoremine uygun olabilmesi içinde her bir kategorinin en az 30 örneklem büyüklüğü olması gerektiğinden bahsedilmektedir (Mayers, 2013: 77). Tabloya bakıldığında deneyimsel pazarlama algısına göre anlamlı bir farklılık tespit edilmiştir. Farklılıkların hangi gruplar arasında olduğunu görmek için Scheffe testine başvurulmuş ve sonuçları Tablo 4'te özetlenmiştir. Buna göre arkadaşlarıyla tatile çıkan katılımcılar ailesiyle tatile çıkan katılımcılardan nispeten daha yüksek ortalamaya sahiptir.

Tablo 4: Katılımcıların Tatile Kiminle Çıktıklarına Göre Deneyimsel Pazarlama Algısının Çoklu Karşılaştırma (Scheffe) Tablosu

\begin{tabular}{|l|l|l|l|l|}
\hline & $\begin{array}{l}\text { Tatile } \\
\text { Kiminle } \\
\text { Çıkıldı }\end{array}$ & & $\begin{array}{l}\text { Ortalama } \\
\text { Farkı }\end{array}$ & $\begin{array}{l}\text { Anlam } \\
\text { Düzeyi }\end{array}$ \\
\hline $\begin{array}{l}\text { Sosyalleşme ve } \\
\text { Merak }\end{array}$ & Arkadaş & Yalnız & $0,46946^{*}$ & 0,002 \\
\cline { 3 - 5 } & Aile & $0,69618^{*}$ & 0,000 \\
\hline $\begin{array}{l}\text { Hizmet } \\
\text { Atmosferi }\end{array}$ & Arkadaş & Aile & $0,63044^{*}$ & 0,000 \\
\hline Ambiyans & Arkadaş & Aile & $0,33433^{*}$ & 0,001 \\
\hline$: p<0,05$ & \multicolumn{3}{|l}{} \\
\hline
\end{tabular}

Tablo 5: Tatile Kiminle Çıktıklarına Göre Müşteri Memnuniyeti Çoklu Karşılaştırma (Scheffe) Tablosu

\begin{tabular}{|l|l|l|l|l|}
\hline & $\begin{array}{l}\text { Tatile Kiminle } \\
\text { Çıkıldı }\end{array}$ & $\begin{array}{l}\text { Ortalama } \\
\text { Farkı }\end{array}$ & $\begin{array}{l}\text { Anlam } \\
\text { Düzeyi }\end{array}$ \\
\hline $\begin{array}{l}\text { Müşteri } \\
\text { Memnuniyeti }\end{array}$ & Arkadaş & Yalnız & $0,45113^{*}$ & 0,021 \\
\cline { 3 - 5 } & Aile & $0,59107^{*}$ & 0,000 \\
\hline
\end{tabular}

Tablo 5'e göre arkadaşlarıyla tatile çıkan katılımcılar yalnız ve ailesiyle tatile çıkan katılımcılardan daha yüksek ortalamaya sahiptir. 
Tablo 6: Katılımcıların Deneyimsel Pazarlama Algıları Boyutlarının Tatillerini Nasıl Organize Ettiklerine Göre Karşılaştırılması

\begin{tabular}{|l|c|c|c|c|c|c|}
\hline & $\begin{array}{c}\text { Tatil Nasıl } \\
\text { Organize Edildi }\end{array}$ & $\mathbf{n}$ & Ortalama & $\begin{array}{c}\text { Standart } \\
\text { Sapma }\end{array}$ & $\begin{array}{c}\text { T } \\
\text { Değeri }\end{array}$ & $\begin{array}{c}\text { Anlam } \\
\text { Düzeyi }\end{array}$ \\
\hline \multirow{2}{*}{ Sosyalleşme ve Merak } & Bireysel & 79 & 3,5967 & 0,62970 & \multirow{2}{*}{2,235} & \multirow{2}{*}{$\mathbf{0 , 0 2 7 ^ { \star }}$} \\
\cline { 2 - 6 } & Seyahat acentesi & 326 & 3,7862 & 0,83981 & & \\
\hline \multirow{2}{*}{ Hizmet Atmosferi } & Bireysel & 79 & 3,6688 & 0,79506 & \multirow{2}{*}{1,803} & \multirow{2}{*}{0,074} \\
\cline { 2 - 6 } Ambiyans & Seyahat acentesi & 326 & 3,8558 & 0,94896 & & \\
\cline { 2 - 6 } & Bireysel & 79 & 3,2405 & 0,73537 & \multirow{2}{*}{0,166} & \multirow{2}{*}{0,868} \\
\cline { 2 - 5 } & Seyahat acentesi & 326 & 3,2569 & 0,97653 & & \\
\hline
\end{tabular}

${ }^{*}: p<0,05$

Tablo 6'ya göre katılımcıların tatillerini nasıl organize ettiğine göre deneyimsel pazarlama algısı "Sosyalleşme ve Merak" boyutunda anlamlı bir farklılık göstermektedir. Ancak, katılımcıların tatillerini nasıl organize ettiklerine göre müşteri memnuniyetlerinin anlamlı bir farklılık göstermediği görülmüştür.

Tablo 7: Katılımcıların Deneyimsel Pazarlama Algısı Boyutlarının Balon Deneyimi Yaşamalarına Göre Karşılaştırılması

\begin{tabular}{|c|c|c|c|c|c|c|}
\hline & $\begin{array}{c}\text { Balon } \\
\text { Deneyimi }\end{array}$ & $\mathbf{n}$ & Ortalama & $\begin{array}{c}\text { Standart } \\
\text { Sapma }\end{array}$ & $\begin{array}{c}t \\
\text { Değeri }\end{array}$ & $\begin{array}{l}\text { Anlam } \\
\text { Düzeyi }\end{array}$ \\
\hline \multirow{2}{*}{ Sosyalleşme ve Merak } & Evet & 344 & 3,7986 & 0,80632 & \multirow{2}{*}{3,106} & \multirow{2}{*}{$0,003^{*}$} \\
\hline & Hayır & 61 & 3,4707 & 0,75112 & & \\
\hline \multirow{2}{*}{ Hizmet Atmosferi } & Evet & 344 & 3,8876 & 0,91480 & \multirow{2}{*}{3,683} & \multirow{2}{*}{$0,000^{*}$} \\
\hline & Hayır & 61 & 3,4344 & 0,88049 & & \\
\hline \multirow{2}{*}{ Ambiyans } & Evet & 344 & 3,2783 & 0,95380 & \multirow{2}{*}{1,423} & \multirow{2}{*}{0,158} \\
\hline & Hayır & 61 & 3,1148 & 0,80308 & & \\
\hline
\end{tabular}

$$
{ }^{*}: p<0,05
$$

Tablo 8: Katılımcıların Müşteri Memnuniyetlerinin Balon Deneyimi Yaşamalarına Göre Karşılaştırılması

\begin{tabular}{|c|c|c|c|c|c|c|}
\hline & $\begin{array}{c}\text { Balon } \\
\text { Deneyimi }\end{array}$ & $\mathbf{n}$ & Ortalama & $\begin{array}{c}\text { Standart } \\
\text { Sapma }\end{array}$ & $\begin{array}{c}\mathbf{t} \\
\text { Değeri }\end{array}$ & $\begin{array}{c}\text { Anlam } \\
\text { Düzeyi }\end{array}$ \\
\hline \multirow{2}{*}{ Müşteri Memnuniyeti } & Evet & 344 & 3,8563 & 0,88635 & \multirow{2}{*}{2,173} & \multirow{2}{*}{$\mathbf{0 , 0 3 0 *}$} \\
\cline { 2 - 6 } & Hayır & 61 & 3,5948 & 0,73918 & \\
\hline
\end{tabular}

${ }^{*}: p<0,05$

Balon deneyimi ile ilgili Tablo 7 ve 8 incelendiğinde, deneyimsel pazarlama algısı ve müşteri memnuniyeti konusunda balon deneyimi yaşan katılımcılar, yaşamayan katılımcılara göre nispeten daha yüksek ortalamalara sahiptirler. 
Tablo 9: Katılımcıların Deneyimsel Pazarlama Algısı Boyutlarının Otelin Niteliğine Göre Karşılaştırılması

\begin{tabular}{|c|c|c|c|c|c|c|}
\hline & $\begin{array}{c}\text { Otel } \\
\text { Niteliği }\end{array}$ & $\mathbf{n}$ & Ortalama & $\begin{array}{c}\text { Standart } \\
\text { Sapma }\end{array}$ & $\begin{array}{c}t \\
\text { Değeri }\end{array}$ & $\begin{array}{l}\text { Anlam } \\
\text { Düzeyi }\end{array}$ \\
\hline \multirow{2}{*}{$\begin{array}{l}\text { Sosyalleşme } \\
\text { Merak }\end{array}$} & Temalı & 203 & 4,1802 & 0,62360 & \multirow{2}{*}{12,769} & \multirow{2}{*}{$0,000^{*}$} \\
\hline & Temasız & 202 & 3,3161 & 0,73398 & & \\
\hline \multirow{2}{*}{ Hizmet Atmosferi } & Temalı & 203 & 4,3054 & 0,65505 & \multirow{2}{*}{12,490} & \multirow{2}{*}{$0,000^{*}$} \\
\hline & Temasız & 202 & 3,3309 & 0,89598 & & \\
\hline \multirow{2}{*}{ Ambiyans } & Temalı & 203 & 3,7463 & 0,77295 & \multirow{2}{*}{12,534} & \multirow{2}{*}{$0,000^{*}$} \\
\hline & Temasız & 202 & 2,7587 & 0,81244 & & \\
\hline
\end{tabular}

${ }^{*}: p<0,05$

Tablo 10: Katılımcıların Müşteri Memnuniyetlerinin Otel Niteliğine Göre Karşılaştırılması

\begin{tabular}{|l|c|c|c|c|c|c|}
\hline & Otel Niteliği & $\mathbf{n}$ & Ortalama & $\begin{array}{c}\text { Standart } \\
\text { Sapma }\end{array}$ & t Değeri & $\begin{array}{c}\text { Anlam } \\
\text { Düzeyi }\end{array}$ \\
\hline \multirow{2}{*}{ Müşteri Memnuniyeti } & Temalı & 203 & 4,3519 & 0,63176 & \multirow{2}{*}{15,745} & \multirow{2}{*}{$\mathbf{0 , 0 0 0 *}$} \\
\cline { 2 - 6 } & Temasız & 202 & 3,2793 & 0,73541 & & \\
\hline
\end{tabular}

${ }^{\star}: p<0,05$

Tablo 9 ve Tablo 10 incelendiğinde, katılımcıların konakladıkları otel niteliğine göre müşteri memnuniyetlerinin anlamlı bir farklılık gösterdiği görülmektedir. Temalı otelde konaklamış katılımcılar, temasız otelde konaklamış katılımcılardan daha yüksek müşteri memnuniyeti ortalamalarına sahiptirler.

Tablo 11: Katılımcıların Deneyimsel Pazarlama Algılarının Memnuniyet Düzeyleri Üzerindeki Etkisine Dair Regresyon Analizi Sonuçları

\begin{tabular}{|l|c|c|c|c|c|}
\hline \multirow{2}{*}{ Model } & \multicolumn{2}{|c|}{$\begin{array}{c}\text { Standardize } \\
\text { Edilmemiş Katsayılar }\end{array}$} & $\begin{array}{c}\text { Standardize } \\
\text { Katsayılar }\end{array}$ & t & p \\
\cline { 2 - 6 } & $\mathbf{B}$ & Std. Hata & Beta & & $\mathbf{0 , 0 0 0}$ \\
\hline (Sabit) &, 835 &, 151 & & 20,097 & $\mathbf{0 , 0 0 0}$ \\
\hline $\begin{array}{l}\text { Deneyimsel } \\
\text { Pazarlama } \\
\text { Algısı }\end{array}$ &, 827 &, 041 &, 707 & & \\
\hline Bağımlı Değişken: Müşteri Memnuniyeti & & & \\
\hline R: 0,707; R2: 0,501; Düzeltilmiş R2: 0,499; Model için F:403,892; $\mathrm{p}=0,000 ;$ s.d.:1 \\
\hline
\end{tabular}

Tablo 11'deki basit doğrusal regresyon analizi sonuçları incelendiğinde, oluşturulan regresyon modelinin anlamlı $(F=403,892 \quad \mathrm{P}<0,01)$ olduğu görülmektedir. Bağımsız değişkenin (deneyimsel pazarlama algısı) bağımlı değişkeni (müşteri memnuniyeti) açıklama oranı R2 değeri 0,501 olarak hesaplanmıştır. Bu sonuç ise, katılımcıların müşteri memnuniyetinin \%50,1'nin deneyimsel pazarlama algıları ile açıklandığını göstermektedir. Öte yandan katılımcıların deneyimsel pazarlama algılarındaki 1 birimlik artış, müşteri memnuniyetlerini 0,827 birim arttırmaktadır. Ayrıca, katılımcıların deneyimsel pazarlama algıları ile müşteri memnuniyetleri arasında pozitif yönlü, kuvvetli ve anlamlı bir ilişki vardır $(r=0,707 ; p<0,01)$. Buna göre 
katılımcıların deneyimsel pazarlama algıları arttıkça müşteri memnuniyetlerinin de arttığı söylenebilir.

\section{Sonuç ve Öneriler}

Bu çalışmada Kapadokya'yı ziyaret eden yabancı turistlerin deneyimsel pazarlama algıları ve deneyimsel pazarlama algılarının memnuniyetlerine etkisi araştırılmıştır. Katılımcıların seyahate en fazla arkadaşlarıyla çıktıkları ve en fazla deneyimin arkadaşlarla edinildiği tespit edilmiştir. Tatile en çok arkadaşla çıkıldığında en fazla deneyimin arkadaşlarla yaşanması doğal bir sonuç olarak karşılanabileceği gibi, aile ile çıkılan tatilin deneyim edinimini azalttığı yorumu da yapılabilir. Aile tatillerinde herkesin aile içerisindeki rolünü oynamak zorunda olması bu sonucun olası açıklamalarından biri olabilir. Bu kısıtlama bireylerin memnuniyetlerinin de düşük çıkmasına katkıda bulunmuş olabilir. Bu sonuç, Kılıç ve Pelit (2014)'in yapmış olduğu çalışmayla benzerlikler göstermektedir.

Katılımcıların çoğu, tatillerini organize ederken seyahat acentelerini tercih ettiklerini belirtmişlerdir. Buna sebep olarak katılımcıların henüz deneyimlemediği bir destinasyona gittiklerinde karşılaşabilecekleri olası sorunlarda muhatap olabilecek bir kişi ya da kurumun olması isteği gösterilebilir. Ayrıca turistler kendilerinin düzenledikleri turlarda sorumluluk almaktan kaçınma ve ekonomik olarak acentelerin avantajlı fiyatlar sunması gibi nedenlerden dolayı da seyahat acentelerini tercih etmiş olabilirler.

Bölgenin önemli çekiciliklerinden biri olan balon deneyiminin yaşanıp/ yaşanmamasının hem deneyimsel pazarlama algısında hem de müşteri memnuniyetinde anlamlı bir farklılığa neden olduğu tespit edilmiştir. Bundan dolayı balon deneyimi yaşandığında katılımcılar otel deneyimini yorumlarken balon deneyimini de dâhil etmiş olabilirler. Sonuç olarak katılımcıların otel deneyimini balon deneyimiyle bir bütün olarak düşündükleri, bu nedenle destinasyonda yaşanabilecek deneyimlerin de otel deneyimlerine birer yansımasının olabileceği düşünülebilir. Kapadokya'nın eşsiz doğal güzelliklerinin kuşbakışı olarak görülmesi turistlerin balon deneyiminden daha fazla haz almasına olanak tanıyor olabilir.

Atay ve Çeti (2018) tarafından botellerde (gemi/tekne temalı otellerde) konaklayan misafirler üzerinde yapılan çalışmada, katılımcıların botellerin manzarası, konumu ve tasarımsal özelliklerinden oldukça etkilendikleri ve bu doğrultuda da temaya bağlı olarak elde ettikleri deneyimlerini olumlu bir şekilde değerlendirdikleri saptanmıştır. Bu çalışmanın bulgusunun çalışmamızın bulgularıyla örtüştüğü görülmüştür. Kapadokya bölgesinde 36 adet temalı otel bulunmaktadır. Temalı otellerin fiyatları temasız otellere göre daha yüksektir. Fakat turistler daha fazla deneyim yaşama olanaklarının olduğunu düşündükleri için fiyat konusunu önemsemeyip bu otelleri tercih etmektedir. Bu bulgu Türkiye'nin ucuz destinasyon imajının, daha fazla temalı oteller açılarak veya var olan oteller temalandırılarak değiştirilebileceğine ilişkin bir ipucu olarak değerlendirilebilir. Hem Kapadokya hem de diğer bölgelerdeki oteller de temalandırılırsa daha fazla konaklama geliri yaratılabileceği yorumu yapılabilir.

Çalışmanın önemli sonuçlarından biri ise, algılanan deneyimsel pazarlama düzeyi ile müşteri memnuniyeti arasındaki yüksek ilişkinin varlığıdır. Bu yüksek ilişki, deneyimsel pazarlama algısının müşteri memnuniyetinin tek başına yarısını açıklıyor olmasından kaynaklanmaktadır. Benzer şekilde otel işletmeleri tarafından misafire sunulan deneyim, onların algıladıkları memnuniyeti birim bazında arttırmaktadır. 
Çalışmanın temelini oluşturan sonuçlardan bir diğeri ise deneyimsel pazarlama algısının tüm alt boyutlarında ve memnuniyet düzeylerinde temalı veya temasız otelde konaklama durumuna göre anlamlı bir farklılaşmanın var olmasıdır. Bulgular incelendiğinde niteliksel olarak farklı olan temalı otellerde konaklayan katılımcıların deneyimsel pazarlama algısının ve müşteri memnuniyetinin temasız otelde konaklayan katılımcılara göre daha yüksek olduğu sonucuna ulaşılmıştır. Bu sonuç, gün geçtikçe daha fazla deneyim merkezli bir hizmet alanı haline gelmekte olan turizm sektöründe ziyaretçilere sunulan deneyimsel ürünlerin önemini ve bunun ziyaretçi memnuniyetinde farklııı yaratma durumunu ortaya koymaktadır. Kapadokya'yı fotoğraflardan görmekle yetinmeyip dokusunu hissetmek için gelen katılımcıların mağara gibi temalı otellerde konaklamayı tercih etmesi bu deneyimi yaşamak istemesinden kaynaklandığı düşünülebilir. Bu kapsamda hem uygulamacılar hem de araştırmacılar açısından aşağıdaki öneriler geliştirilebilir:

$>\quad$ Temalı otellerin, temasız otellere göre daha yüksek geceleme fiyatına ve daha fazla müşteri memnuniyetine sahip olmasından hareketle daha fazla müşteri memnuniyeti ve daha fazla gelir elde etmek isteyen otel işletmelerine, sahip oldukları otellerini bir temaya kavuşturmaları, ayrıca müşterilerinin yaşayacakları deneyimleri sahneleyebilecekleri bir ortam hazırlamaları önerilebilir.

> Kapadokya bölgesi için yapılabilecek bir diğer öneri ise peri bacaları gibi turistik noktaların hikayeleştirilmesi üzerinden olabilir.

$>\quad$ Bir diğer öneri festivallere yöneliktir. Mağara, han vb. temalarda uygun görülen zamanda bir festival ile ziyaretçilere farklı deneyimler yaşatılabilir. Bu deneyim ise, ziyaretçileri temalı otellerde konaklama konusunda teşvik edebilir.

> Kapadokya bölgesindeki bir diğer kültürel öğe ise, kökeni geçmişe dayanan şarapçılık geleneğidir. Şarabı ile ünlü olan bölgede, bağ evlerinin temalı otellere dönüştürülmesi bir diğer öneri olarak sunulabilir.

$>\quad$ Bir diğer öneri ise, balon deneyiminden doğmaktadır. Destinasyonda fazladan yaşanabilecek bir deneyimin, müşterilerin otelin sunmuş olduğu deneyimleri olumlu algılamalarını ve memnuniyetlerini arttırabildiği görülmektedir. Buradan yola çıkarak, otel işletmeleri ile balon işletmelerinin kendi aralarında ikili anlaşma yapmaları öneri olarak sunulabilir.

Araştırmaya sadece Kapadokya'ya tatile gelen yabancı turistler dahil edilmiştir. Farklı destinasyonlardan daha fazla işletme ve/veya yerli turist de araştırmanın içerisine dahil edilebilir. Ayrıca, nicel araştırma yöntemine ek olarak, nitel araştırma yöntemlerinden bazıları da eklenerek deneyimsel pazarlama konusu daha kapsamlı olarak ele alınabilir.

Çalışmada temalı otellerde konaklayan katılımcıların deneyimsel pazarlama algısı ve müşteri memnuniyetinin temasız otellerde konaklayan katılımcılara göre anlamlı şekilde farklılaştığı sonucuna ulaşılmıştır. Bu bağlamda katılımcılar için temel intiyaç olan konaklamanın yanı sıra, konaklanan yerin niteliği ve temalı olması katılımcıların hazsal tüketim dahilinde hareket ettiğini göstermektedir. Bu nedenle, gelecek araştırmalar için hazsal (hedonik) tüketim gibi konular üzerinden, temalı ve temasız otellerde kalma durumu arasındaki ilişki incelenebilir.

\section{Kaynakça}

Aho, S. K. (2001). Towards A General Theory of Touristic Experiences: Modeling Experience Process in Tourism. Tourism Review, 56 (3, 4), 33-37. 
Akkaya, D. H., ve Usman, E. E. (2012). Temalı Otel: Yok-Mekanla Var Edilmeye Çalışılan 'Kurgu Mekan'. Tasarım+ Kuram Dergisi, 7(11-12), 67-82.

Alpar, R. (2013). Uygulamalı Çok Değişkenli İstatistiksel Yöntemler, Ankara: Detay Yayıncılık.

Alpar, R. (2016). Spor, Sağlık ve Eğitim Bilimlerinden Örneklerle Uygulamalı İstatistik Ve Geçerlik - Güvenirlik. Ankara: Detay Yayıncılık.

Altıntaş, M. H. (2000). Tüketici Davranışları: Müşteri Tatmininden Müşteri Değerine. İstanbul: Alfa Basımevi.

Ardıç Yetiş, Ş. (2015). Termal Otel İşletmelerinde Deneyimsel Pazarlama Yaklaşımı. KMÜ Sosyal ve Ekonomik Araştırmalar Dergisi, 17 (29), 90-98.

Atay, L. ve Çeti B. (2018). Temalı Otellerde Konaklayan Turistlerin Deneyimlerinin Belirlenmesi: Botel Örneği. MANAS Sosyal Araştırmalar Dergisi, 7(1), 555-572.

Bassi, F. ve Guido, G. (2006). Measuring Customer Satisfaction: From Product Performance to Consumption Experience. Journal of Consumer Satisfaction, 19, 76-88.

Bulgan, G. ve Soybalı, H. H. (2011). Antalya Belek Bölgesindeki Beş Yıldızlı Otel İşletmelerinde Düşük Sezonda Konaklayan Alman Müşterilerin Hizmet Beklentilerinin Ve Memnuniyet Düzeylerinin Değerlendirilmesi. Journal of Yaşar University, 21(6), 3572-3597.

Chen, H. J., Wong, S. W., Bilgihan, A., ve Okumus, F. (2020). Capsule Hotels: Offering Experiential Value or Perceived as Risky by Tourists? An Optimum Stimulation Level Model. International Journal of Hospitality Management, 86, 1-10.

Çeltek, E. (2010), Deneyimsel Pazarlama Unsurlarının Otellerin Bakış Açısı İle Değerlendirilmesi: Türkiye'deki 4 ve 5 Yıldızlı Otel İşletmelerinde Bir Uygulama, Yayınlanmamış Doktora Tezi, Anadolu Üniversitesi Sosyal Bilimler Enstitüsü, Eskişehir.

Dilsiz, B. (2010), Otelcilik Gelecek Trendi 'Dizayn Oteller', http://www.turizmgazetesi.com/news.aspx?ıd=51704 adresinden 6.11.2019 tarihinde ulaşılmıştır.

Genç, B. (2009). Deneyimsel Pazarlamanın Tüketici Satın Alma Kararlarına Etkisi. Yayınlanmamış Yüksek Lisans Tezi, Ege Üniversitesi Sosyal Bilimler Enstitüsü, İzmir.

Gentile, C., Spiller, N., ve Noci, G. (2007). How To Sustain The Customer Experience: An Overview of Experience Components That Co-Create Value With the Customer. European Management Journal, 25(5), 395-410.

Gilmore, J. H., ve Pine, B. J. (2002). Differentiating Hospitality Operations Via Experiences: Why Selling Services Is Not Enough. Cornell Hotel And Restaurant Administration Quarterly, 43(3), 87-96.

Güney D. (2015). Deneyimsel Pazarlamanın Müşteri Sadakatine Etkisi: Muğla'daki Butik Otellere Yönelik Bir Uygulama. Yayınlanmamış Yüksek Lisans Tezi, Muğla Sıtkı Koçman Üniversitesi Sosyal Bilimler Enstitüsü, Muğla.

Harman, S.,ve Akgündüz, Y. (2014). Efes Örenyeri Ziyaretçilerinin Müze Deneyimi Beklentilerini Belirlemeye Dönük Bir Araştırma. Gazi Üniversitesi İktisadi ve İdari Bilimler Fakültesi Dergisi, 16(2), 113-133.

Holbrook, M., B. ve Hirschman E., (1982). The Experiential Aspects Of Consumption: Consumer Fantasies, Feelings and Fun. Journal of Consumer Research, 9, $132-140$.

Hung, K. (2015). Experiencing Buddhism in Chinese Hotels: Toward the Construction of a Religious Lodging Experience. Journal of Travel \& Tourism Marketing, 32(8), 1081-1098.

Jurowski, C. (2009). An Examination of the Four Realms of Tourism Experience Theory. International CHRIE Conference-RefereedTrack. 
Kara, M., ve Çiçek, B. (2015). Deneyimsel Pazarlama ve Satın Alma Karar Sürecine Etkisi: Termal Turizm Sektöründe Bir Uygulama. Gümüşhane Üniversitesi Sosyal Bilimler Enstitüsü Elektronik Dergisi, 6(13).

Kılıç, İ. ve Pelit, E. (2004). Yerli Turistlerin Memnuniyet Düzeyleri Üzerine Bir Araştırma, Anatolia: Turizm Araştırmaları Dergisi, 15 (2), 113-124.

Köse, B. Ç. (2015). Turizm Perspektifinde Deneyimsel Pazarlamanın Davranışsal Niyetler Ve Tatmin Üzerindeki Etkisi: Üçüncü Yaş Grubu Turistler Üzerinde Bir Araştırma. Yayınlanmamış Doktora Tezi, Trakya Üniversitesi Sosyal Bilimler Enstitüsü İşletme Anabilim Dalı.

Kültür ve Turizm Bakanlığı, (2018), Belediye-Bakanlık Belgeli Tesis Konaklama İstatistikleri. http://yigm.kulturturizm.gov.tr/tr-201122/belediye-belgeli-tesiskonaklama-istatistikleri.html adresinden 6.11.2019 tarihinde ulaşılmıştır.

Lewis, R. C. ve Chambers, R. E. (2000) Marketing Leadership in Hospitality. New York: John Wiley.

Mayers, A. (2013). Introduction to Statistics and SPSS in Psychology. London: Pearson.

Milman, A. (2001). The Future of the Theme Park And Attraction Industry: A Management Perspective, Journal of Travel Research, 40, 139-147.

O'Sullivan, E. L. ve Spangler, K. J. (1998). Experience Marketing: Strategies for the New Millennium. State College, Pennsylvania: Venture Publishing.

Oh, H.,Fiore, A. M. ve Jeoung, M. (2007) Measuring Experience Economy Concepts: Tourism Applications. Journal of Travel Research, 46, 119-132.

Olıver, R., L.; (1997). Satisfaction: A Behavioral Perspective on the Consumer, New York: McGraw-Hill.

Oliver, R. L., (2015). Satisfaction: A Behavioral Perspective on the Consumer, 2.Baskı, Routledge, New York.

Özbay, A. V. (2011). Müşteri Memnuniyetinin Ölçülmesi: Turizm Sektörü Üzerine Bir Alan Araştırması, Yayınlanmamış Yüksek Lisans Tezi, Anadolu Üniversitesi Sosyal Bilimler Enstitüsü, Eskişehir.

Özen, S. (2009). Dünya Turizminde Tüketici Tercihlerinde Yaşanan Değişimlerin Konaklama İşletmelerine Yansımaları: Antalya'da Temalı Otel Örnekleri. Yayınlanmamış Yüksek Lisans Tezi, Adnan Menderes Üniversitesi Sosyal Bilimler Enstitüsü, Aydın.

Pine, J. ve Gilmore, J. H. (1998). Welcome to The Experience Economy, Harvard Business Review, 76, 97-105.

Pine, J. ve Gilmore, J. H. (1999). Deneyim Ekonomisi: Iş Hayatı Bir Tiyatro Ve De Her Şirket Bir Sahne. (Çev.: L. Cinemre). İstanbul: Boyner Holding Yayınları.

Rather, R. A. (2020). Customer experience and engagement in tourism destinations: the experiential marketing perspective. Journal of Travel \& Tourism Marketing, 37(1), 15-32.

Schmitt, B. (1999). Experiential Marketing, Journal of Marketing Management, 15(1-3), 53-67.

Türk Dil Kurumu (2018). "Deneyim”, “Duyusal” ve "Davranışsal” adresinden 6.11.2019 tarihinde ulaşılmıştır.

Walls, A. R., Okumus, F., Wang, R.Y. ve Kwun, D. J. W. (2011). An Epistemological View of Consumer Experiences. International Journal of Hospitality Management, 30,10-21.

Yuan, Y.H., ve Wu, C.K. (2008). Relationships Among Experiential Marketing, Experiential Value, and Customer Satisfaction, Journal of Marketing, 33 (3), 387389. 